RESEARCH ARTICLE

\title{
THE ROLE OF THE NUSANTARA TASK FORCE IN PREVENTING POLITICAL VULNERABILITY IN THE PATI POLICE JURISDICTION
}

\author{
Arindra Wigrha Pratama \\ Central Java Regional Police Department, Indonesia \\ $\bowtie$ arindra.pratama@gmail.con
}

\section{CITED AS}

Pratama, A.W. (2020). The Role of The Nusantara Task Force in Preventing Political Vulnerability in the Pati Police Jurisdiction. Journal of Law and Legal Reform, 1(3), 457478. DOI: https://doi.org/10.15294/jllr.vli3.36702

\section{ABSTRACT}

Political insecurity ahead of the 2019 presidential and vice-presidential election candidates often arises in the Pati Police jurisdiction. The establishment of this task force aims to minimize the occurrence of various political vulnerabilities ahead of the presidential and vice=presidential elections so as not to develop into social conflict. The purpose of this study is to analyze the problems of political vulnerability that existed during the 2019 Presidential Election in the Pati Police jurisdiction, describe and explain the role of the Nusantara Task Force in preventing the occurrence of problems of political vulnerability that existed during the 2019 Presidential Election in the Pati Police area, and analyze the factors influencing the implementation of the Task Force of the Archipelago in preventing the occurrence of problems of political insecurity that existed during the 2019 Presidential Election in the Pati Police jurisdiction. Theories used in this research are the Role Theory and Voter Behavior Theory. The concept used is the Nusantara Task Force Concept. The laws and regulations in this study are Law No. 2 of 2002 concerning the National Police and the Law. No. 7 of 2017 concerning General Elections, as well as National Police Chief Sprin No. Sprin / 40 / I / 2018 Date January 8, 2018 About the Establishment of the Task Force Nusantara.

Keywords: Nusantara Task Force; Prevention; Political Vulnerability; 2019 Presidential Election 


\section{TABLE OF CONTENTS}

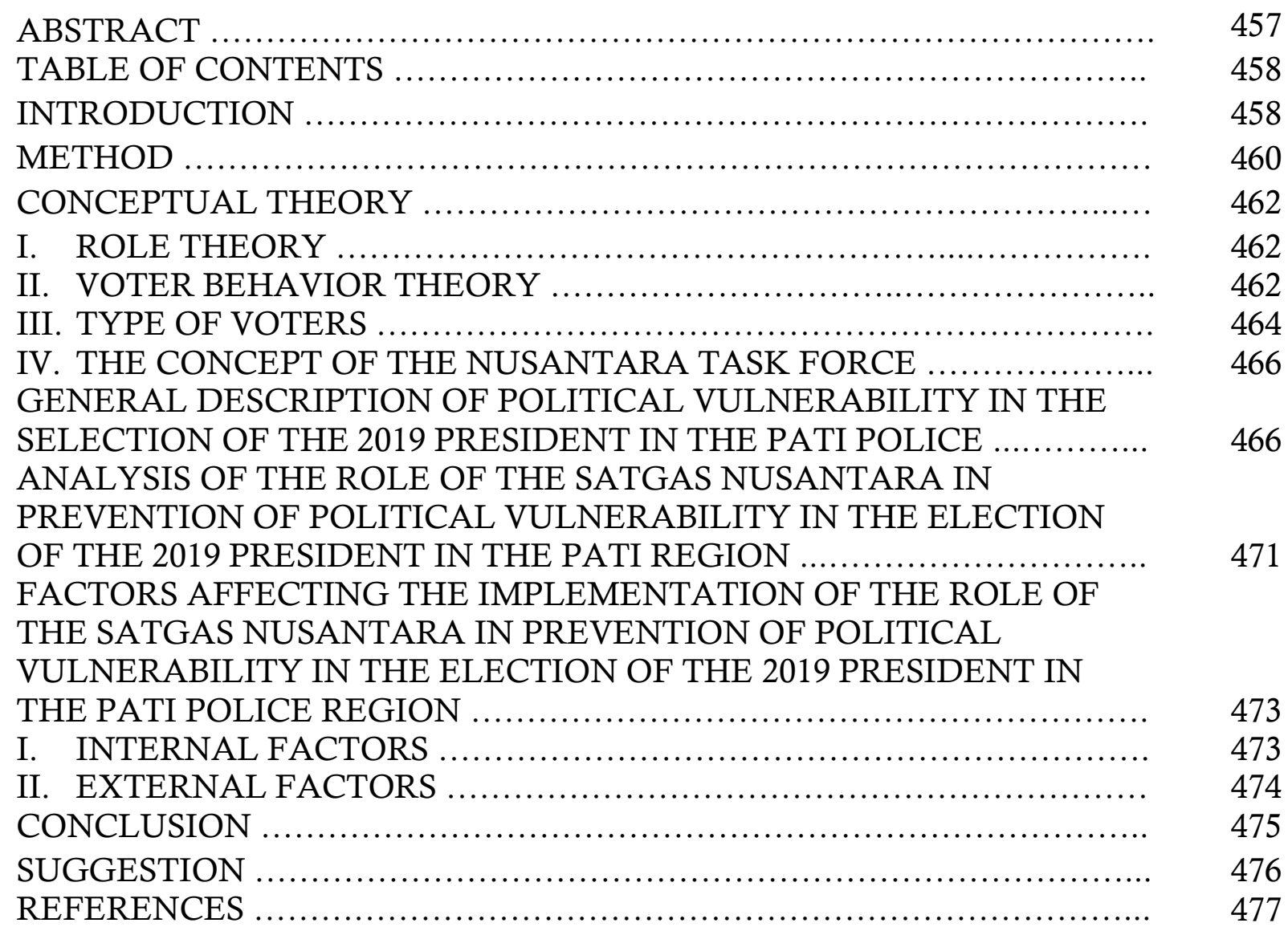

\section{INTRODUCTION}

The implementation of general elections (hereinafter referred as Elections), both Legislative Elections, Presidential Elections or Regional Head Elections are always colored by various political vulnerabilities. This happened because each contestant tried to win the attention of the public so that he was elected in the election period. This political vulnerability varies, ranging from negative campaign actions aimed at bringing down the opposing party, black campaigns, hate speeches, hoax information dissemination and various potential occurrence of Kamtibmas disruption caused by the ideological conditions of the community.

Moreover, in this region many members of HTI even though currently passive, the existence of one of the bases of the former G 30 /PKI which is currently ex G 30S/PKI is active in the YPKP (Victim of Murder Victims Research Foundation) 65. 
This problem has always been a figure that worrying and frightening because this can have potential as something that does not support the implementation of the democratic party in Indonesia.

This concern was strongly felt by the Pati regency government which found various problems in the implementation of a democratic party in the Pati region, one of which was the finding of many people who preferred not to exercise their relatively large voting rights, which is more than $25 \%$ of the total public voters in Pilkada in Pati Regency.

This can occur because of the various perceptions that can shake his imagination in organizing a democratic party in the Pati region, as a result he has a doubtful attitude or feels psychological terror that resulted in him reluctant to engage more deeply in the political problem, this is also supported by the assumption of the findings of the number of people who prefer not to use their voting rights which present the number of people who do not support the Pati regency government in the future, this is considered to worry the Pati regency government and be a disruptive factor in the administration of Pati regency policy in the future.

Based on the study of documents from the data collected in Pati Regency KPU, related to the implementation of the election of regional heads and deputy regional heads (Pilkada) of Pati Regency, it was found the list of permanent voters in Pati Regency was 697,437 people. The results of other studies found that people who used their voting rights were 519,675 people or $74.512 \%$ and those who did not exercise their voting rights were 177,762 people or $25.487 \%$. The existence of the people who do not exercise their right to vote is also considered to be able to eliminate the legitimacy of the leadership of the Pati regency government which subsequently is able to lead to conditions that are not conducive to other political insecurities in the efforts of Pati regency development as well as other implementation of government activities. This happens because the political participation of the people related to the implementation of the elections is a very important form of democracy and can influence the formulation, making and decision making, as well as the implementation of the Pati regency government policy in the future.

The emergence of the above problems can further influence the socio-economic conditions of the community, the psychological condition of the community, the Kamtibmas condition to the political conditions in the Pati Police Precinct. These problems can have a negative impact on society during the reign of the elected regional head. These assumptions arise based on the potential for disruption in the administration of government bureaucracy which has attention in this direction will be divided, so that the focus of the Government is not only in the implementation of 
the Government bureaucracy but also focuses on solving various problems that arise in the implementation of the bureaucratic process, especially when in the administration democratic party in the region.

To overcome Kamtibmas's disturbances both as a psychological terror in the community and tangible disturbances, Pati Pati Police has carried out various preemptive, preventive and repressive strategies so that people in the Pati Police jurisdiction feel peace, security and public order. One form of preemtive strategy in the policy of overcoming the problem of social and political vulnerability.

Pati Police through the formation of the Nusantara task force have made efforts to provide guidance and counseling to the citizens of Pati Regency so that they remain calm in the face of the current situation. The other functions of the Nusantara task force in supporting Pilkada in Pati Regency are also being prepared to be aware of various threats to Kamtibmas disruption during the campaign period and during the Pati Regency Regional Election, as well as to anticipate various Kamtibmas disruptions that exist in the administration of Pati Regency Election by taking preventive, preemptive and repressive actions. However, the results of the formation of the Nusantara Task Force were not fully optimal in suppressing the presence of Abstentions in this region, which could be due to the inability of the Nusantara task force to influence the community so that they were actively involved in organizing the democratic party.

Seeing these problems, the Pati District Police must further enhance the role of the Nusantara task force so that in the implementation of the elections it is free from various socio-political insecurity issues, so that the Nusantara task force can prevent and avoid various problems both sectoral egos of one group or other Kamtibmas disruption aimed at disrupting democratic process held in this region. The increase in the role of the Nusantara task force in preventing various socio-political tensions during the Regional Election is also expected to prevent black campaigns and money politics, avoid conflict and political violence, prevent the domination of the elites playing in the elections, and prevent, overcome and stop political mobilization, so that the Nusantara task force can restore people's position as a central figure in creating popular sovereignty.

\section{METHOD}

The research literature used as a reference in conducting this research includes, first, Rian Sacipto, 2018. The Existence of the National Police in Law Enforcement of 
Election Crimes Welcoming the Indonesian Democracy Party 2019. National Seminar on Law at Semarang State University Volume 4 Number 2 of 2018, 366-385.

This research is motivated by the problem of the large number of violations in the holding of elections and various crime problems committed by supporters and from political parties, both directly and indirectly to political contestants. The purpose of this study is to explain the role of the National Police in creating quality elections.

The research method was carried out through a field research method with a qualitative approach. The results of this research include the efforts of the National Police in creating quality, honest and fair Elections carried out in collaboration with the Prosecutors' Office, KPU and Bawaslu in analyzing, filtering and categorizing an act of criminal violation or Election administration.

Second, Binov Handitya. 2018. The Role of the Integrated Law Enforcement Center (Gakkumdu) in Enforcing Election Crime. National Seminar of Law Semarang State University Volume 4 Number 2 of 2018, 348-365

Research conducted by Binov (2018) is motivated by the problem of the rise of money politics practices in each election period, the cause is none other than the lack of public awareness of elections that can make a vehicle for the enforcement of people's sovereignty. The purpose of this study is to explain the role of the Gakkumdu Center in the enforcement of election crime. This research was conducted with a qualitative approach and using field research methods. The results of this study, among others, explained the legal basis in carrying out the role of the Gakkumdu Center as in Article 486 paragraph (1) of Law No. 7 of 2017 concerning General Elections, which explicitly explains that the Gakkumdu Center was formed to equalize the role in the act of election criminal acts from several elements such as the National Police, the Attorney General's Office, KPU and Bawaslu which all of these functions have the same vision and mission namely suppressing the occurrence of Election criminal acts in the upcoming 2019 Presidential Election.

Based on the background explanation above, the formulation of the problem in this study is how is the role of the Nusantara task force in preventing political insecurity in the Pati Police jurisdiction? Based on the formulation of the problem, the main issues in this study include:

1. Problems of political insecurity that existed during the 2019 Presidential Election in the Pati Police jurisdiction. 
2. The role of the Nusantara Task Force in preventing the occurrence of problems of political insecurity that existed during the 2019 Presidential Election in the Pati Police jurisdiction.

3. Factors influencing the implementation of the Task Force of the Archipelago in preventing the occurrence of problems of political insecurity that existed during the 2019 Presidential Election in the Pati Police jurisdiction.

\section{CONCEPTUAL THEORY}

The conceptual literature that will be used in this study consists of several theories and concepts as follows:

\section{ROLE THEORY}

The role (role) is a dynamic process of status (status). If a person exercises his rights and obligations according to his position, he carries out a role. The difference between position and role is in the interest of science. Both cannot be separated because one depends on the other and vice versa (Soekanto, 2009: 212).

\section{VOTER BEHAVIOR THEORY}

Voters who became king in the implementation of the democratic party became the main goal of the contestants to support and vote for the contestants. A person who is declared as a voter in an Election is a person who has been registered as a voter participant by an official registering voters. When viewed from political and ideological institutions, the Voters can be in the form of constituents and society in general. The voters referred to in the constituency are a group of people who feel represented by certain ideologies that are manifested in political institutions such as political parties and a leader (KPU Ponorogo, No Year: 48).

According to Surbakti (1997 in KPU Ponorogo, No Year: 48), voter behavior is the activity of voting by individuals who are closely related to the decision-making activities to vote or not to vote (to vote or not to vote) in an election. Based on this explanation, it is understood that the behavior of voters can vote and determine who will be elected as the Regional Head and Deputy Regional Head in a direct election, which is shown by the behavior of the community in electing candidates for Regional Head and Deputy Regional Head candidates. 
The decision to provide support and votes will not occur if there is not a high enough voter loyalty to the prospective leader. Vice versa, voters will not vote if they think that a party or prospective leader is not loyal and is not consistent with the promises and expectations they have given.

Voter behavior is also laden with ideology between voters and political parties or election contestants. Each contestant carries an ideology that interacts with each other. During the election campaign period, crystallization and grouping emerged between the ideologies brought by the contestants. The public will classify themselves to contestants who have the same ideology taken with those they profess while also distancing themselves from ideologies that are opposite them (KPU Ponorogo, Without Years: 48). Voter behavior can also be analyzed with three approaches, namely:

\section{Sociological Approach}

This approach is used to explain the voting behavior of the British people, who refer to the sociological approach as a social determinism approach. This approach basically explains that social characteristics and social groupings have a significant influence in determining the behavior of a voter. Social characteristics (such as work, education, etc.) and sociological characteristics or background (such as religion, region, gender, age, etc.) are important factors in determining political choices (Andrew A. Abeyta, 2019).

In short, social groupings such as age (young and old); gender (male); religion and the like are considered to have a quite decisive role in forming formal social groupings such as one's membership in religious organizations, professional organizations: as well as informal groupings such as family, friendship or other small groups, which is something very vital in understanding one's political behavior, because these groups have a major role in shaping one's attitudes, perceptions and orientation (KPU Ponorogo, No Year: 52).

\section{Psychological Approach}

Psychological approach is a phenomenon that was fully developed by the people of the United States through the Survey Research Center at the University of Michigan. Therefore, this approach is also referred to as the Michigan School. The main pioneer of this approach is Angust Campbell. This approach uses and develops psychological concepts, especially the concept of socialization and attitudes to explain voter behavior. Socialization variables and attitudes cannot be related to voting behavior if there is a socialization process. Therefore, according to this 
approach it is actually socialization that determines a person's (political) voting behavior.

Adherents of this approach explain a person's attitude - as a reflection of one's personality - is a quite decisive variable in influencing one's political behavior. Therefore, the psychological approach emphasizes on three psychological aspects as the main study, namely emotional ties in a political party, orientation to issues and orientation to candidates (KPU Ponorogo, No Year: 54).

\section{Rational Approach}

The use of a rational approach in explaining voter behavior by political scientists is actually adapted from economics. They see an analogy between the market (economy) and voting behavior (politics). If economically the community can act rationally, that is, to reduce costs as little as possible to obtain the maximum profit, then even in political behavior the community will be able to act rationally, namely to vote for the OPP which is considered to bring the maximum profit and reduce losses (KPU Ponorogo, No Year: 55). Voter Orientation can also be divided into two, namely:

\section{a. Policy-Problem Solving Orientation}

When voters judge a contestant from the lens of "policy-problem-solving" the most important thing for them is the extent to which contestants are able to offer work programs or solutions to an existing problem. Voters will tend to objectively vote for political parties or contestants who have sensitivity to national (regional) problems and clarity of political party work programs or election contestants whose unclear policy direction will tend to be unselected (KPU Ponorogo, No Year: 56).

\section{b. Orientation of Ideology}

Voters who tend to prioritize the ideology of a party or contestant, will prioritize the bonding "ideology" of a party or contestant, will emphasize aspects of subjectivity such as the closeness of values, culture, norms, emotions and psychographics. The closer the similarity of parties or election contestants, this type of voters will tend to vote to the party or contestant (KPU Ponorogo, Without Year: $57)$.

\section{TYPE OF VOTERS}

\section{Rational Voter}


The ability of these so-called high voters has a high orientation towards PolicyProblem-Solving and is low oriented towards ideological factors. Voters in this case prioritize the ability of political parties or candidates participating in the election with their work program, they see the work program through the performance of parties or contestants in the past, and the program offer offered by the candidate or political party in solving various problems that are happening. This type of voter has a characteristic that is not so concerned with ideology ties to a political party or a contestant. The most important thing for this type of voter is what can (and has) been done by a party or an election contestant (KPU Ponorogo, No Year: 58).

\section{Critical Voter}

The process to become a type of voter can occur through 2 things:

a. This type of voter makes the ideological value as a foothold to determine which party or contestant the election will side with and then they will criticize the policy that will or has been done.

b. It could also be the other way around where voters are interested first in the work program offered by a party / contestant and then try to understand the values and understandings behind the making of a policy. This type of voters are critical voters, meaning they will always analyze the links between the ideological party system and the policies made (KPU Ponorogo, No Year: 59).

\section{Traditional Voter}

This type of voter has a very high ideological orientation and does not really see the policy of a political party or a contestant as something important in decision making. Traditional voters prioritize the socio-cultural closeness, values, origins, understanding and religion as a measure to choose a political party or contestant election. Policies such as those related to economic issues, welfare, education, etc., are considered as second priority. Voters of this type are very easy to mobilize during the campaign period, voters of this type have a very high loyalty. They consider what is said by an election contestant or political party which is a truth that can not be negotiable (KPU Ponorogo, Without Years: 60).

\section{Skepsis Voter}

This type of voter does not have a high enough ideological orientation with a political party or election contestant, nor does this voter make a policy an important matter. Even if they participate in elections, they usually do it randomly. They believe 
that whoever wins in the election, the results are the same, there are no significant changes that can be divided for regional / state conditions (KPU Ponorogo, No Year: $61)$.

\section{THE CONCEPT OF THE NUSANTARA TASK FORCE}

The Nusantara task force is a task force formed by the National Police Chief in accordance with the National Police Chief Order No: SPRIN / 40 / I / 2018 regarding the formation of the National Satgas in charge of minimizing the occurrence of provocative issues related to Primordialism (SARA) issues so as not to develop into social conflicts in the implementation of simultaneous local elections in in order to maintain the unity and integrity of the nation through two approaches, namely the soft approach (through the implementation of intelligence, community service and public relations tasks) and the hard approach (through proportional and professional law enforcement) in order to maintain the unity and integrity of the Indonesian nation, with the aim of carrying out its tasks aimed at an activity, person / group, and certain place / location.

The formation of the Nusantara task force is one of the implementations of the leadership's policy in anticipating vulnerabilities that occurred during the elections, which are based on Law No. 2 of 2002 concerning the Indonesian National Police, and several other laws and regulations (Polri, 2018: 3 )

\section{GENERAL DESCRIPTION OF POLITICAL VULNERABILITY IN THE SELECTION OF THE 2019 PRESIDENT IN THE PATI POLICE}

Pati Regency has held the General Election of DPRD Members (Pileg) directly four times, namely in 1999, 2004, 2009 and 2014. The 1999 legislative election was a direct legislative conducted by Pati Regency. The 1999 legislative election was attended by 48 parties. The 1999 Legislative Election was won by PDIP with an absolute victory for all districts in Pati Regency with 326,580 votes and 21 seats. The party with the most votes gained was the PKB with 133,006 votes and won 9 seats.

The implementation of the second Pileg Pati in 2004 was attended by 24 parties. This 2004 legislative election produced 9 parties that won seats in the DPRD. The 2004 DPRD Member Election was again won by the PDIP which again won an absolute election in all districts with a total vote of 214,996 and won 16 seats. The 
second party that gained the most votes was PKB with 123,395 and managed to get 9 seats.

Pati's third pileg was held in 2009, which was participated by 44 political parties. The 2009 legislative election was won again by the PDIP with 141,547 votes won absolutely in all districts, so that PDIP won 12 seats in the Pati Regency DPRD. Then followed by the Democratic Party with 95,590 votes and managed to get 8 seats. 2014 legislative election was the fourth legislative election for Pati Regency, which was participated by 12 parties. Based on the vote acquisition data, PDIP returned to the party that gained the most votes in the 2014 legislative election. However, in the 2014 legislative election, PDIP did not win absolutely for all districts. PDIP competes fiercely with the Gerindra Party. So that the acquisition of the final results for the PDIP and Gerindra Party is not far adrift, namely 117,664 and 112,599 by getting the same number of seats in the DPRD which is as many as 8 seats.

Based on the above legislative election data, it can be concluded that PDIP is the party that won the majority of votes in Pati Regency, as evidenced by the implementation of four legislative elections, PDIP always gained the most votes, even three times the legislative elections namely 1999, 2004 and 2009 PDIP won absolutely in all districts.

The political parties participating in the Legislative Election were able to carry their cadres. This shows that the political parties are competitive. The political parties also showed that they had carried out the function of political recruitment well and prepared their cadres who had the competence to compete with cadres from other political parties.

In addition to holding the Legislative Election, Pati regency has also held Regional Elections and Deputy Regional Heads four times, namely in 2006, 2011, 2012 and 2017 Re-election which was the first direct Pemilukada in Pati Regency, as well as the regional elections that made Pati Regency a public spotlight at the national level. That is because the participation rate of Pati Regency voters is only 44.3 percent. Based on data obtained by Kompas Research and Development, voter turnout in the 2006 General Election was 51.8 percent. Looking at these data, the participation rate of Pati Regency, which ranges between 44 percent, makes Pati Regency the title of the region with the lowest political participation in Central Java. This causes disruption to the government bureaucracy because the results of the post-conflict local election do not represent all the aspirations of the people of Pati Regency.

In addition, the 2006 post-conflict local election also led to demonstrations from Pati District residents who are members of a group calling themselves the Concerned Pilkada Concerned Communities (Gampil), with at least 5,000 members. The 
demonstration was carried out because all pairs of candidates for regent proposed were claimed by the masses to be involved in legal issues. The 2006 post-conflict local election was attended by four candidate pairs, namely Tasiman-Kartina Sukowati, Kotot Kusmanto-Arsyad, Sudjoko-Sunandar and Slamet Warsito-Anik Syahuri.

The Pati Regency KPU and Central Java KPU claimed that they were not authorized to cancel the post-conflict local election. The authorized party to postpone or cancel the post-conflict local election implementation process is with the Minister of the Interior by considering the input of the Central KPU. Cancellation of postconflict local elections can be done if special things happen such as natural disasters, while the legal case against all pairs of candidates for regent and deputy regent of Pati regency is only based on the allegations of the community.

The 2006 post-conflict local election was won by the pair Tasiman-Kartina Sukowati with a total vote of 195,599 or 46.44 percent. The Tasiman-Kartina Sukowati couple who are promoted by the Democratic Party and PDIP get the highest votes in each district except Kayen District.

The current condition of politics in the Pati Police jurisdiction can also be explained by the holding of the 2019 Presidential Election. Facing the upcoming elections on April 17, 2019, various potential Kamtibmas disruptions exist in the Pati Police jurisdiction. Some potential Kamtibmas disruptions that were successfully identified in the holding of the General Election, especially the 2019 Presidential Election by ICW, which explained some potential Kamtibmas disruptions that are almost in all regions of Indonesia originated from these problems:

1. The case of candidate buying or nominating buying and selling practices that occur between elected candidates and political parties

2. The existence of dynastic political problems that occur in certain areas

3. Presence of names of problematic candidates such as ex-convicts or suspected corruption

4. The existence of a single candidate in several areas

5. The emergence of campaign problems that have relatively high costs due to an increase in the contribution of campaign funds, and the effect of granting permits to selected candidates to provide goods with a maximum price of Rp 25,000.00 to the DPT (permanent voter list).

6. Problems with buying and selling business licenses, buying and selling positions and bribery practices for government projects,

7. There are problems with the politicization of government programs such as grants, social assistance, village assistance, and other prone to providing budget assistance for political party campaigns. 
8. Bureaucracy politicization of state officials such as bureaucrats, ASN, teachers to Polri / TNI institutions

9. The existence of political vulnerability that is applied in buying and selling votes

10. There are problems with manipulation of source reports and use of campaign funds

11. The existence of bribery practices to the election organizers

12. There are cases of corruption for the collection of campaign capital obtained through the sale and purchase of business licenses, buying and selling of office permits to the issue of corruption in the use of certain development budgets. (Results of Document Studies in the 2018 ICW Report, February 28, 2019)

Based on the observations of researchers, it is known that the potential for successfully identified conflicts that exist in almost every region, especially in the Pati Police jurisdiction, during the 2019 Presidential Election, it is known that the potential for conflict comes from various problems as follows:

1. The existence of conflict triggering factors originating from defense candidates, which can be done through abuse of office through the practice of bureaucratic politicization.

2. The emergence of conflict caused by the potential for politicization of the bureaucracy, by involving ASN, Polri and the TNI in the General Election.

3. The emergence of conflict caused by the practice of money politics

4. The emergence of conflict caused by an error in the implementation of data recapitulation

5. The emergence of conflict caused by the presence of KPUD alignments at the district level and the attitude of the Election Supervisory Body that is not fair

6. The emergence of conflicts caused by violations of election criminal offenses, such as the issue of SARA, Hoax, Black Campaign, Hate Speech, etc.

Other potential Kamtibmas disturbances in the Pati Police jurisdiction, which were discovered by researchers from the results of the document study in the General Election Hazard Index Report established by the Election Supervisory Body in 2019. problems with changes in the Permanent Voters' List, violations in the implementation of the campaign, potential disruption of logistical distribution problems (sending selected ballots), potential errors in the voting process and counting errors related to the results of vote counting, as well as dispute problems in the voter list updating stage Still based on the aspects of suffrage and the number of voter participation, where based on further search results, this Pati district has a conflict vulnerability level of $39.29 \%$ which is in the medium category. 
Based on the results of a document study on the Basic Intelligence Pati Pati in 2018, it is known that the potential disruption of Kamtibmas in the Pati Police jurisdiction which can also turn into political vulnerability can be identified by:

1. The existence of study groups suspected of being sympathizers or supporting acts of terrorism aimed at establishing an Indonesian state based on Islamic law / caliphate. These study groups will likely continue to grow, they will form new networks by carrying out activities that can recruit the general public.

2. The existence of Ex. G 30S / PKI through the YPKP (Victim of Murder Victims Research Foundation) 65 including in the jurisdiction of Pati Police, who want to fight for their rights back through legal efforts to rehabilitate their good name. This is a latent danger of communism which is feared that communist teachings could develop again in the territory of the Republic of Indonesia.

3. The prediction of someone who is a former HTI (Hizb ut-Tahrir Indonesia) community organization, who has a different ideology and is in conflict with Pancasila and the 1945 Constitution, namely those who will form a state based on the Caliphate. Even though the government has officially dissolved it, it does not rule out that they will metamorphose to form a new organization considering that the HTI mass organization has management and membership in the Pati Police Precinct.

4. The existence of certain parties is possible to take advantage of issues of religious intolerance for the interests of the Pilkada or the Election as happened in the DKI Jakarta Pilgub in 2017 so that it has the potential to cause disruption of Kamtibmas which will affect the national Kamtibmas situation.

5. An increase in political party funds from Rp. 108, - to Rp. 1.000, - / valid votes received by the party in the last election aimed at improving political education and accommodating the aspirations of the people. The increase in data is prone to fraud by certain elements.

6. The existence of substantial village fund assistance sourced from the APBN regulated and managed by the village aims at village development with a priority to improve the welfare of rural communities and the quality of human life and poverty reduction. However, the community does not yet have the skills in managing these funds so that this is prone to criminal acts of corruption / misuse of village funds committed by related parties.

The observations show that the implementation of the 2019 Presidential Election in the Pati Police jurisdiction was colored with the vulnerability of Kamtibmas disturbance which could also be a political vulnerability which among others also stemmed from competition between each of the supporters of the Presidential 
Candidate. This social insecurity can emerge as a political insecurity because of the various actions of these sympathizers. One example of the sympathetic competition over the support teams is the result of competition which then results in election violations and political insecurity that manifests in various issues such as the issue of suffrage, violations in the campaign, problems in the implementation of the ballot, many adjudication actions that occur stated objections related to the results of votes in the General Election, and other problems.

\section{ANALYSIS OF THE ROLE OF THE SATGAS NUSANTARA IN PREVENTION OF POLITICAL VULNERABILITY IN THE ELECTION OF THE 2019 PRESIDENT IN THE PATI REGION}

Based on the observations of researchers, the high potential for political vulnerability that occurred in the Pati Police area before the 2019 Election period can be prevented if the community also has an understanding of the content of political education, so that every individual community will be free from exploitation resulting from the existence of political vulnerability. However, it feels very difficult to do due to the lack of public understanding of the meaning of the election, thus the community only believes that the election is identical to the problems of negative campaigns, hoaxes, hate speeches and even money politics.

To overcome these potential Kamtibmas disturbances, according to the results of interviews conducted with Pati Pati Wakasgas Archipelago Pati, explained that so far Pati Police have made various efforts to prevent the occurrence of political insecurity because of their knowledge of political insecurity as well as the occurrence of hate speeches on social media or even developing ones in the community it is very difficult to be revealed which could be due to the condition of the community covering up the problem.

Based on further explanations, it is also known that to prevent the occurrence of political vulnerability in the jurisdiction of Pati formed the Task Force of the Archipelago which is intended to keep Pati in the legal area of Pati remain safe from various potential political vulnerabilities during the Election.

Based on the results of the study of documents, it is known that the basis of the implementation of the task force of the Nusantara Task Force is Law Number 2 of 2002 concerning the Indonesian National Police, Law Number 10 of 2016 concerning 
the Second Amendment to Law Number 1 concerning Election of Governors, Regents and Mayor Becomes Law, Law Number 19 Year 2016 Regarding Amendments to Law Number 11 Year 2008 Regarding Information and Electronic Transactions, Law Number 40 Year 2008 Regarding the Elimination of Discrimination, Race and Ethnicity, Work Plan of the Police Chief in 2018 , KUHP, Kirka Intelligence, and Sprin Kapolri No .: Sprin / 40 / I 2018 Dated January 8, 2018 Concerning the Establishment of the Nusantara Task Force.

The implementation of these tasks is in accordance with the roles as explained in the theory of roles that can carry out their rights and obligations in accordance with their position in the community as mandated by the state to him (Soekanto, 2009: 212). In carrying out the role of the Task Force of the Archipelago, he carried out this task in accordance with the functions of the National Police whose task was to maintain public order and security in order to maintain a safe, secure and peaceful social structure in the face of the 2019 elections. In accordance with the theory of that role, the role of the Task Force in the effort to prevent Political vulnerability in the Pati Police jurisdiction carries out various activities as follows:

1. Conduct early detection activities

2. Identifying the problem

3. Mapping the problem

4. Carrying out action to mobilize community guards or experts who cause Kamtibmas disturbance

5. To provide guidance to community and community leaders

6. Doing social activities

7. Doing opinion counters and narrative counters as well

8. Perform Lidik and Sidik activities (investigation).

With the role of the Nusantara task force members, it can be applied to the public in detail that the implementation of these tasks is in accordance with the Pati Police Resort in preventing political insecurity during the 2019 Elections, where with this role, the Nusantara task force can also provide an explanation of the social position in the economy, education, government and also science among the many categories to describe the implementation of the tasks carried out by members of the Nusantara Task Force, so as to produce behavior in which people change their attitudes and behavior to match social norms existing, and in many cases which can then be internalized into every social role, whether related to the rights, obligations, expectations, behavior and also norms of a person to face and fulfill a situation that exists in the community. 


\section{FACTORS AFFECTING THE IMPLEMENTATION OF THE ROLE OF THE SATGAS NUSANTARA IN PREVENTION OF POLITICAL VULNERABILITY IN THE ELECTION OF THE 2019 PRESIDENT IN THE PATI POLICE REGION}

In carrying out the role of the Task Force of the Archipelago to prevent the occurrence of problems of political insecurity that existed during the 2019 Presidential Election in the Pati area, there are several factors that influence it. Based on the results of the study, it was found that the implementation of the prevention of political insecurity during the General Election in the Pati Police jurisdiction organized by members of the Nusantara task force was influenced by factors originating from:

\section{INTERNAL FACTORS}

Internal factors influence the Task Force of the Nusantara in the implementation of preventing the occurrence of political insecurity during the General Election in the Pati Police jurisdiction. Internally there are several factors that influence the success of the Nusantara task force in the implementation of preventing the occurrence of political insecurity during the General Election in the jurisdiction of Pati Polres including from the knowledge and capabilities of the Pati Polres Task Force personnel on Pati issues regarding the triggers for political insecurity and the negative impact of the problem that can directly disrupt the security and order conditions of the community and the holding of the upcoming 2019 Election, so that the moment of the Election can be constrained and not held properly.

Based on the writer's observation, the obstacle encountered by members of the Pati Police Task Force in preventing the occurrence of political insecurity lies not only in the ability of the Nusantara task force personnel, but also comes from the problem of knowledge of the Nusantara task force personnel regarding their legal review of various rules in Election violations, especially the law that prohibits them, their criminal threats, their negative impact on the welfare of the community directly on the implementation of the General Elections marked by various problems of disorderly Kamtibmas in the political field, as well as the negative impact of political insecurity on the future of the community. As a result of members lack of 
understanding of these elements, this will certainly hinder members of the Task Force Nusantara in convincing the public to jointly carry out preventive actions against political insecurity in the Pati Polres' jurisdiction.

Another problem that exists from Nusantara task force personnel is originating from the limited members of the personnel, which based on the results of document studies it is known that Nusantara task force members in the Pati Police jurisdiction only have 51 members, of course this is a problem. in making efforts to prevent the occurrence of political insecurity that exists in all villages in the Pati Police legal area. But the problem of limited knowledge and ability as well as the number of Nusantara task force personnel in the Pati Police jurisdiction, which is in the effort to prevent the occurrence of political insecurity in the Pati Police jurisdiction, is helped by the policy of the Kapolres which requires all its members to provide assistance in carrying out the task of the Nusantara task force namely together to prevent the existence of political vulnerability in the Pati Police jurisdiction.

Other facilities used for the implementation of efforts to prevent the occurrence of political insecurity during the Election in the Pati Police jurisdiction are also obtained from the provision of facilities from various institutions or other institutions. This can be observed in activities that have an element to urge the public so that they do not become victims of exploitation of various things that are forms of election violations, such as haox, black campaign, hate speech delivered on local radios owned by certain stakeholders, and the National Police can broadcast it based on the support of facilities from these stakeholders so that efforts to prevent political insecurity during the General Election in the Pati Police jurisdiction can be carried out properly.

\section{EXTERNAL FACTORS}

External factors affect the Task Force of the Archipelago in the implementation of preventing the occurrence of political insecurity during the General Election in the Pati Police jurisdiction. In addition to internal factors as explained above, there are several other factors (external factors) that affect the success of efforts to prevent political vulnerability during the Election in Pati Pati's jurisdiction. These factors stem from the social conditions of the community in the Pati Police jurisdiction. Based on the observations of researchers, the social conditions of the community in the Pati Police jurisdiction influence the success in preventing political insecurity during the Election in the Pati Police jurisdiction. 
Based on the observations of researchers, it is known that other factors that influence the success in preventing the occurrence of political vulnerability during the Election in the jurisdiction of Pati Police also come from the condition of the relationship between Pati Police with the community, and other agencies. or other agencies. With this good relationship, the public, public agencies will easily accept invitations from Pati Police to take certain actions such as preventing political insecurity in this election

This explanation is also in accordance with what was conveyed by members of the community in the Pati Police jurisdiction who also stated that they would work together to secure the implementation of this election from various potential disruption of Kamtibmas, both from personal attacks on the occurrence of money politics practices, as well as from various threats the other

Based on the results of research on the factors that influence the Nusantara task force in preventing political insecurity during the General Election in the Pati Police area, it is found that these factors originate from internal factors derived from the number of Nusantara task force personnel, the ability and knowledge of the Nusantara task force Pati Police, Pati Kapolres policy, availability of infrastructure facilities and budget support from the Kapolres personally, the accuracy of the choice of methods for preventing political vulnerability and the good ability of members to establish good relations between Pati Polres members and community leaders, stakeholders and all levels of society in the jurisdiction Pati Police. In addition to these internal factors, the implementation of the prevention of political vulnerability is also influenced by external factors originating from the social and cultural conditions of the community in the Pati Police jurisdiction, and advances in information technology that can be put to good use by the wider community.

\section{CONCLUSION}

Based on the results and discussion above it can be concluded that the description of political insecurity during the 2019 Presidential Election in Pati Police area comes from the behavior of voters or sympathizers from each party or supporters of each presidential candidate, which is then easily politicized by the interests of certain parties or persons in order to bring down the opposing parties thus making the political conditions in the Pati Police jurisdiction heat up. The Role of the Task Force of the Archipelago in preventing political insecurity during the 2019 Presidential Election in the jurisdiction of Pati Police in accordance with the Sprin Kapolri No :. Sprin / 40 / I / 2018 Dated January 8, 2018 About the Establishment of the Task Force 
of the Archipelago which was carried out by carrying out early detection actions, identification problems, mapping problems, carrying out actions to mobilize community guards or experts who cause Kamtibmas disruption, conducting guidance to community and community leaders, conducting social activities and conducting counter opinions and counter narratives and conducting investigations and investigations, the Task Force of the Archipelago also had to prepare Operation Mantap Brata namely to ensure the readiness of security in all Pati areas, which subsequently is aimed at preventing political insecurity in the face of the 2019 Elections both from the presidential and legislative elections.

Factors influencing the implementation of the Task Force of the Archipelago in preventing political insecurity during the 2019 Presidential Election in the jurisdiction of Pati Polres are divided into two, namely: Factors supporting the role of the Task Force in preventing political vulnerability during the 2019 Presidential Election were clear rules of law, and the availability of infrastructure that could be used by the Task Force in preventing political vulnerability in the region. The inhibiting factors of the Nusantara task force's role in preventing political insecurity during the 2019 Presidential Election came from the limited number of personnel, the limited knowledge of members regarding various potential political vulnerabilities, the absence of a specific budget for the operations of the Nusantara task force and the existence of conditions that were easily provoked by parties who were not to be responsible.

\section{SUGGESTION}

In connection with the findings and discussion concluded in the sub-chapter above, suggestions that can be given by researchers related to the problem of this study can be used to increase the role of the National Task Force in preventing political insecurity during the 2019 Elections in the Pati Police jurisdiction:

1. Making an integrated performance planning both by the regional government and the National Police, which can then provide operational assistance for securing the area in order to prevent political vulnerability carried out by the Nusantara task force so that the problem of personnel limitations can be properly addressed

2. Implement a reward and punishment system to all Pati Police members, who actively provide assistance to the Task Force Nusantara in efforts to prevent the occurrence of political insecurity in the Pati Police jurisdiction.

3. Carry out coaching to members of the Task Force Nusantara, which can be done through providing skills training or providing political education so that members 
have extensive knowledge about politics, the potential for security disturbances in the political field as well as various legal rules regarding violations of election criminal offenses as well as efforts prevention so that members of the Task Force Nusantara can be more active in detecting the potential for political vulnerability in the Pati Police jurisdiction.

4. Collaborating with various community leaders to carry out activities to prevent potential political vulnerabilities in the Pati Police area.

5. Make public service advertisements on electronic media, print media, and social media that contain appeals to the public regarding peaceful elections

\section{REFERENCES}

Abeyta, A.A. (2019). The pushes and pulls of the past: The effects of attachmentrelated avoidance and nostalgia on approach-oriented social goals. Personality and Individual Differences 149(1), 200-208.

Arifin, R., \& Hidayat, S.N. (2019). Organizing Democracy through General Elections in Indonesia: The Challenge of Law Enforcement and State Stability. SOSPOL: Jurnal Sosial Politik 5(2), 333-344. https://doi.org/10.22219/sospol.v5i2.7670 .

Arifin, R. (2020). Crimes and Society, How Do the Law Respond to Disruptive Conditions?. Law Research Review Quarterly,6(1), i-iv. Retrieved from https://journal.unnes.ac.id/sju/index.php/snh/article/view/37437.

Arifin, R. (2020). Legal Reform Discourse in Indonesia and Global Context: How Does The Law Respond to Crime. Journal of Law and Legal Reform, 1(2), 193-196. https://doi.org/10.15294/jllr.vli2.37057.

Arifin, R., \& Putri, W.O. (2019). Penegakan Hukum Terhadap Anggota Legislatif dalam Kasus Tindak Pidana Korupsi di Indonesia. Al Daulah: Jurnal Hukum Pidana dan Ketatanegaraan 8 (1), 1-15.

Handitya, B. (2018). Peran Sentra Penegakan Hukum Terpadu (Gakkumdu) dalam Penegakkan Tindak Pidana Pemilu. Seminar Nasional Hukum Universitas Negeri Semarang 4(2), 348-365.

Indrawan, R., \& Yuniawati, P. (2017). Metodologi Penelitian Kuantitatif, Kualitatif dan Campuran untuk Manajemen, Pembangunan, dan Pendidikan. Bandung: PT Refika Aditama.

KPU Ponorogo. Tanpa tahun. Pilkada dan Politik Uang. Tanpa Kota Terbit: Ebook. 
Masyhar, A., \& Arifin, R. (2018). Urgensi Pembentengan Masyarakat dari Radikalisme dan Terorisme (Upaya Terhadap Jamiyyah Nahdlatul Ulama Kecamatan Bonang Kabupaten Demak). Jurnal Pengabdian Hukum Indonesia 1(1), 1-12. Retrieved from https://journal.unnes.ac.id/sju/index.php/JPHI/article/view/27259.

Muthia, F.R., \& Arifin, R. (2019). Kajian Hukum Pidana Pada Kasus Kejahatan Mayantara (Cybercrime) Dalam Perkara Pencemaran Nama Baik di Indonesia. RESAM Jurnal Hukum 5 (1), 21-39. DOI: https://doi.org/10.32661/resam.v5il.18.

Pamungkas, A.D., \& Arifin, R. (2019). Demokrasi dan Kampanye Hitam dalam Penyelenggaraan Pemilihan Umum di Indonesia (Analisis atas Black Campaign dan Negative Campaign). DIKTUM: Jurnal Syariah dan Hukum 17 (1), 16-30. DOI: https://doi.org/10.35905/diktum.vl7il.64l.

Polri. (2013). Peraturan Kapolri No. 23 Tahun 2010 Tentang Susunan Organisasi dan Tata Kerja Pada tingkat Kepolisian Resert dan Kepolisian Sektor

Polri. (2018). Surat Perintah Kapolri No:SPRIN/40/I/2018 Tentang Pembentukan Satgas Nusantara.

Polri. (2001). Surat Keputusan Kapolri No. Pol: Skep/1503/X/2001 tentang Buku Petunjuk Administrasi Struktur, Eselonisasi, dan Penggolongan Jabatan dalam Kepangkatan di Lingkungan Organisasi Polri.

Polri. (2018). Pembekalan Kanusantara task force pada Rapim Polri Tahun 2018 Polri. (2019). Intel Dasar Polres Pati Tahun 2019

Polri (2018). Intel Dasar Polres Pati Tahun 2018

Pranesti, D.A., \& Arifin, R. (2019). Perlindungan Korban dalam Kasus Penyebaran

Berita Hoax di Media Sosial di Indonesia'. Jurnal Hukum Media Bhakti 3 (1), 8-17. DOI: https://doi.org/10.32501/jhmb.v3il.35.

Republic of Indonesia. (2002). Undang-undang No. 2 Tahun 2002 Tentang Kepolisian Negara Republik Indonesia.

Republic of Indonesia. (2010). Surat Keputusan KPU Nomor 13 Tahun 2010 tentan Pedoman Teknis Tata Cara Pencalonan Pemilihan Umum Kepala Daerah dan Wakil Kepala Daerah.

Sacipto, R. (2018). Eksistensi Polri dalam Penegakan Hukum Tindak Pidana Pemilu Menyongsong Pesta Demokrasi Indonesia 2019. Seminar Nasional Hukum Universitas Negeri Semarang 4(1), 366-385.

Soekanto, S. (2009). Sosiologi Suatu Pengantar. Jakarta: Bina Aksara.

Utari, I. S., \& Arifin, R. (2019). Law Enforcement and Legal Reform in Indonesia and Global Context: How the Law Responds to Community Development?. Journal of Law and Legal Reform, 1(1), 1-4. https://doi.org/10.15294/jllr.vlil.35772 